IJ§ER

ISSN: 2149-5939
International Journal of Social Sciences and Education Research

Online, http://dergipark.gov.tr/ijsser

Volume: 1(2), 2015

\title{
Europeanization of Union Rights: A comparative analysis between Tur- key and Croatia
}

\author{
Zühal Ünalp Çepel ${ }^{1}$
}

\begin{abstract}
Received Date: 01 / 02 / 2015
Accepted Date: $01 / 04 / 2015$

Abstract

The Europeanization process has a considerable impact on the fundamental rights within the candidate and member countries. Within this framework, reforms on union rights in the domestic realm have been one of the significant determinants of Europeanization. Turkey's harmonization process with the European Union (EU) acquis started in 1999 with Helsinki Summit. In this process, it seems to be essential to make more reforms on union rights. Considering Copenhagen criteria, the problems dealing with this issue pose a serious obstacle to the membership process of Turkey. On the other hand, Croatia which became a candidate country in 2004 and was granted the membership status in 2013, passed through a rapid harmonization process on union rights. The paper is based on the Europeanization literature in defining union rights. It is aimed to find answers to the questions of which steps were taken in Turkey and Croatia within the context of freedom of association and social dialogue, why Croatia came a long way in those matters although the country started negotiations with the EU much later than Turkey.
\end{abstract}

Keywords: Freedom of Association, Trade Unions, Social Dialogue, Turkey, Croatia

\section{Introduction}

After Croatia became an independent state in 1992, the EU membership was determined as a primary goal by the political leaders who had a considerable support from the society. The first democratic elections were held in 2000, and the new government started to contact with the EU decision-makers. In 2001, Stabilization and Association Agreement between Croatia and the EU was signed. This agreement gave Croatia the status of both 'associate membership' and 'potential candidacy' (Čehulić-Vukadinović, 2013, pp.51,53). As a result, the Europeanization process of the country started.

In 2002 and 2003, two reports were prepared by the EU on freedom of association and trade unions in Croatia. In the first report, the need for more cooperation between state and trade unions, and problems in the sphere of civil society were stressed. In the second report, diminishing financial support to civil society organizations was criticized and the ratification of European Social Charter was positively elaborated (Stubbs and Zrinšèak, 2005, p.172). In 2004, Croatia was declared as one of the candidate countries of the EU. With the decision of European Council, accession negotiations started in 2005 . The other candidate country at that time was Turkey. In this process, Croatia had been quite responsive to EU conditionality, and the strong state capacity has let the Europeanization work inside the country (Börzel, 2011, p.14). Croation leaders and civil society have been strongly in agreement to adopt the reform agenda (Cierco, 2009, p.191).

The accession negotiations between Croatia and the EU were closed in 2011, and Croatia became a member country in 2013 (Eurofound, 2012, p.2). Even if Croatia has met policial and

\footnotetext{
${ }^{1}$ Ph. D,Dokuz Eylül University, International Relations, IZMIR/TURKEY, zuhal.unalp@deu.edu.tr 
Ünalp Çepel, Z. (2015). Europeanization of Union Rights: A comparative analysis between Turkey and Croatia. International Journal of Social Sciences and Education Research, 1 (2), 355-366.

economic criteria, the Europeanization process and harmonization with the EU acquis have been going on especially within the context of the rule of law and market economy. The most prominent issues in the sphere of the rule of law are public administration and judicial system, corruption and organized crime. Although there is a functioning market economy in the country, structural reforms are still necessary in order to overcome the bad effects of economic crisis surrounding Europe (European Commission, Monitoring Report on Croatia, 2012, p.9).

On the other hand, Turkey has aimed to be a part of the European integration since 1959, two years after the Treaty of Rome. Formal relations started with 1963 Ankara Agreement which established an assocation between Turkey and the EU. Turkey's application for full membership to the European Community (EC) in 1987 had been one of the significant steps taken for the consolidation of democracy in the country. The aim was to lessen the negative effects of the 1980 military coup and accelerate transition to democracy. However the EC delegates stressed that Turkey had a weak democracy, and there had been many issues in the country needed to be handled (Dağ1, 1997, pp.128,147). Moreover deepening and widening dilemma in the EC and Greece's veto for Turkey's membership also influenced the process negatively (Huntington, 1996, p.278). Within the context of enlargement policy, the priority was given to Austria, Sweden and Finland. Central and Eastern European countries followed them with their membership in 2004 and 2007.

Turkey's EU candidacy status which was granted in 1999 made a significant contribution to the comprehensive democratization initiatives on fundamental rights and freedom of association. The term between 2001 and 2006 represents a high-speed legal reform process. Europeanization process has triggered modernization and democratization efforts inside the country (Tocci, 2009, p.82). However many factors such as political problems between Turkey and the EU countries, Turkey's becoming relatively distant from the EU candidacy process, transformation process of Turkish foreign policy have caused the slowdown of the reform process. In Turkey, such developments in different historical periods of time have caused the Europeanization process to continue in varying degrees (Kaliber, 2013, p.66).

In this paper, within the context of union rights, freedom of association and social dialogue mechanisms in the EU are explained; and the impetus of Europeanization on the reforms in Turkey and Croatia on freedom of association and social dialogue mechanisms are analyzed. The processes in both countries are compared in order to find an answer why Turkey has not been successful in reforming union rights.

\section{Europeanization and Union Rights}

Europeanization is a process and it depends on the misfit thesis between the domestic and European policies, rules, norms, principles and institutions. This process aims to increase the possibility of convergence among national systems in Europe. The convergence process depends on a top-down or a bottom-up process. For a candidate country, a top-down process shapes the national system. Various academicians define Europeanization as the direct impact of European integration on domestic policies, political structure and institutions. The academicians determine processes, interactions and policies in European level as the independent variables; domestic impact as the dependent variable (Featherstone and Radaelli, 2003; Schimmelfennig and Sedelmeier, 2005). This paper is also based on the same argument. On union rights, the EU has a considerable impact on the candidate countries through the social policy instruments and institutions 
Ünalp Çepel, Z. (2015). Europeanization of Union Rights: A comparative analysis between Turkey and Croatia. International Journal of Social Sciences and Education Research, 1 (2), 355-366.

(Cerami, 2008, p.4). From this viewpoint, in order to explain union rights, Copenhagen criteria (political criteria including freedom of association, freedom to establish and join unions, freedom of speech, strike and lockout, etc.), European/national level social dialogue mechanisms and trade union organizations are analyzed.

Copenhagen criteria which were established in the Copenhagen European Council in 1993 cover the union rights. The criteria have been significant instruments of Europeanization (Sedelmeier, 2011, p.17). They are consisted of political, economic and the EU acquis spheres. In the political sphere, candidate countries must meet the criteria of the stability of institutions guaranteeing democracy, the rule of law, human rights and respect for and protection of minorities. The candidates must have the ability to take on obligations of membership, including adherence to the aims of political, economic and monetary union. The criteria on union rights are apparent in political and the EU acquis spheres. The progress reports published by the European Commission indicate that union rights in a candidate country are analyzed under the title of 'human rights and the protection of minorities' within the context of political criteria. In this section, freedom of association, freedom of assembly, freedom of speech, the establishment and functioning of trade unions, labour law, right to strike and right to collective bargaining in the candidate country are analyzed. Union rights are also analyzed under the title of 'social policy and employment' within the context of adopting the EU acquis. In this section, labour law, employment policy and social dialogue mechanisms in the candidate country are analyzed.

Union rights in the EU are guaranteed with the Charter of Fundamental Rights of the EU and the Treaty on the Functioning of the EU. The Charter of Fundamental Rights of the EU which was adopted at the Nice Summit in 2000 and entered into force in 2009 with the Lisbon Treaty, regulates the civil, political, economic and social rights in the EU. The Charter was prepared by taking into consideration the rights in the EU member state constitutions, in the European Convention on Human Rights (ECHR), the European Social Charter, the Community Charter of Fundamental Social Rights of Workers, and the other international agreements that the member states had signed (Kaczorowska, 2011, p.242). This fact indicates that Europeanization process on union rights cannot be reduced to the European Union. The EU acquis is linked closely with the rules and norms of Council of Europe and International Labor Organization (Vaughan and Kilcommins, 2007, p.440).

One of the rights protected by the EU Charter of Fundamental Rights is freedom of association which has a great importance for union rights. According to Article 12 of the Charter, the freedom of association is defined as in the following:

"Everyone has the right to freedom of peaceful assembly and to freedom of association at all levels, in particular in political, trade union and civic matters, which implies the right of everyone to form and to join trade unions for the protection of his or her interests".

Freedom of association is regulated also in Article 151 of the Treaty on the Functioning of the EU. In this article, fundamental social rights are defined as in the following:

"The Union and the Member States, having in mind fundamental social rights such as those set out in the European Social Charter signed at Turin on 18 October 1961 and in the 1989 Community Charter of the Fundamental Social Rights of Workers, shall have as their objectives the promotion of employment, improved living and working conditions, so as to 
Ünalp Çepel, Z. (2015). Europeanization of Union Rights: A comparative analysis between Turkey and Croatia. International Journal of Social Sciences and Education Research, 1 (2), 355-366.

make possible their harmonisation while the improvement is being maintained, proper social protection, dialogue between management and labour, the development of human resources with a view to lasting high employment and the combating of exclusion".

The articles above are influential instruments of Europeanization. Adopting the EU acquis on union rights is a condition for a candidate country to be a member country. The other significant instruments for Europeanization of union rights are social dialogue mechanisms in the EU. At those mechanisms, non-governmental organizations are represented in order to support and protect union rights. European Trade Union Confederation, The Council of European Professional and Managerial Staff and European Federation of Retired and Older People are some of the significant organizations. According to International Labor Organization (ILO), social dialogue includes all types of negotiation, consultation or simply exchange of information between, or among, representatives of governments, employers and workers, on issues of common interest relating to economic and social policy. In paralel to this definition, European social dialogue covers discussions, consultations, negotiations and joint actions of the employers and workers. Even if there is no common social policy in the EU, social dialogue mechanisms are protected under the EU legislation. The concept of social dialogue took place in the EU legislation firstly with Maastrict Treaty in 1992. With the Amsterdam Treaty which came into force in 1999, social partners had the right to be consulted on social and economic issues, and they started to participate in legislation processes. According to Article 152 of Lisbon Treaty, the EU has a significant role to ease dialogue between the social partners (Güray, 2013, p.147).

The most significant institution trade unions have a voice in the EU is the European Economic and Social Committee. The Committee was established in 1957 with the Treaty of Rome. According to Article 301 of Lisbon Treaty, the number of members in the Committee is limited to 350. Three groups -employers, workers and various interest groups- are represented within the Committee. The groups offer their suggessions to the Commission and the Council. The European Parliament consults the Economic and Social Committee in related matters. Recently it has been obligatory for the Commission to take advices of the Economic and Social Committee on the issues related to Common Agricultural Policy, labour mobility, convergence of laws, social policy, European Social Fund, employment policy and public health (Kaczorowska, 2011, p.178). Social dialogue can be both in national and local levels. The candidate and member countries of the EU establish local and national social dialogue mechanisms by modelling European Economic and Social Committee. The other social dialogue mechanisms in the EU are Tripartite Social Summit for Growth and Employment, Intersectoral Social Dialogue, Sectoral Social Dialogue Committees and Advisory Committees (European Commission, 2011). Those mechanisms have a considerable impact on the EU directives on economic and social issues and contribute to social, industrial and economic progress of the countries.

Despite of the instruments explained above, Europeanization process depends on the support of domestic institutions (Börzel and Risse, 2000, p.2). In this respect, in order to compare Europeanization process of union rights in Turkey and Croatia, policies and implementation processes of the EU acquis in the domestic realms are analyzed.

\section{A comparative analysis on Union Rights: Turkey and Croatia}

Turkey and Croatia have signed international agreements in order to guarantee union rights. Being a part of the agreements has contributed to the Europeanization of union rights within the 
Ünalp Çepel, Z. (2015). Europeanization of Union Rights: A comparative analysis between Turkey and Croatia.

International Journal of Social Sciences and Education Research, 1 (2), 355-366.

countries. However it seems to be different in practice. In this section, union rights in Turkey and Croatia are analyzed comparatively under two topics; freedom of association and social dialogue mechanisms.

\subsection{Freedom of association in Turkey and Croatia}

In Turkey, laws on freedom of association are harmonized with the EU acquis (2012 Progress Report, p.23). In the first Progress Report for Turkey which was published in 1998, it was stressed that freedom of association had been limited; civil organizations had organized their activities only by getting permission from the authorities; and the civil organizations had been prevented to invite foreign organizations to Turkey (1998 Progress Report, p.16). In fourteen years, legal reforms and harmonization packages in Turkey let significant progress on freedom of association. On October 3, 2001, Article 33 in the constitution which covers freedom of association was changed (Usul, 2011, p.125). This was one of the 34 changes made in 1982 Constitution to meet Copenhagen criteria. In 2002, within the framework of the third harmonization package, the context of associational activities were extended; and the obstacles for the freedom of association of public servants were removed (2001 Progress Report, p.14). Until 2008, nine reform packages were implemented, significant reforms on Law of Associations and Law of Foundations were held. However the EU policy of Turkey has lost its dynamism since 2008, and harmonization efforts were not continued.

In Croatia, freedom of association is guaranteed for every citizen by Article 43 of the Croatian Constitution. The interests of all social, economic, political and cultural groups are protected by this law. Therefore, there is no need to get permission from the authorities to establish an association or a trade union. According to Law of Associations, Law of Foundations and Endowments which came into force in 2001, public servants, members of army, police and judiciary have the right to establish associations or trade unions. However army and police organizations may be restricted by law (2005 Progress Report, p.89). According to Bertelsmann Transformation Index (an index which evaluates the quality of democracies), freedom of association and assembly rights are as 10 between 2006 and 2012 in Croatia (Balkır and Aknur, 2015, p.89).

On the other hand, the European Commission criticized the restrictive legislation on freedom of association in Turkey in the last Progress Report (Turkey 2014 Progress Report, p. 59). Although it was simplified to establish a trade union organization in Turkey, laws are not harmonized with the EU and ILO standards at all. According to Article 51 of 1982 Constitution, employees and employers have the rights to establish trade union, join and not to join a union, decide to leave or remain a member of a union freely in order to protect their economic and social rights and interests. On the other hand, the right to collective bargaining is defined in the Article 53 of the constitution. According to this article, employees and employers have the right to collective bargaining to structure their economic and social positions and working conditions. Although Turkey ratified Convention No. 98 (the right to organize and collective bargaining) in 1951, and Convention No. 87 (the freedom of association and protection of the right to organize) in 1992, she does not meet ILO standards especially within the context of these Conventions (Başbuğ, 2012, pp.17,21,65). On the other hand, Turkey ratified the Revised European Social Charter in 2007, since it represented European social norms, and Turkey aimed at harmonization with the European social norms as a candidate country (Gülmez, 2007, p.34). Despite of the ratification, Turkey has put reservations on Article 5 (the right to organize) and Article 6 (the right to bargain collectively) (2006 Progress Report, p.18). These rights are two of the fundamental rights in the Charter, 
Ünalp Çepel, Z. (2015). Europeanization of Union Rights: A comparative analysis between Turkey and Croatia. International Journal of Social Sciences and Education Research, 1 (2), 355-366.

and they are closely linked with the other rights in the Charter (Council of Europe, 1997, p.8). Therefore putting reservations on those articles damages the entirety of the Charter. In this regard, the standards on freedom of association, right to bargain collectively and to strike are not implemented in Turkey (European Commission, 2007, p.57). However Croatia meets ILO standards on union rights by signing and implementing Convention No. 87 and Convention No. 98 in 1991. Based on the mentioned standards, workers in Croatia are free to establish or join trade unions. Croatia signed the Revised European Social Charter in 2009, but has not ratified it yet (Council of Europe, 2013, p.1). There are significant problems in the Croatian labour market needed to be tackled. Although discrimination in the workplace is prohibited by laws, female workers are payed lower than men. Especially women in Romani population are exposed to discrimination in the labour market (ITUC, 2010, p.1).

The EU stresses that workers' rights in Turkey are limited; workers are exposed to be fired from job because of trade union memberships and other union activities. And those facts are not handled by the courts efficiently. By drawing the attention to the union protests in Turkey, the EU states that the protests are negatively perceived by the authorities; there are limitations and use of excessive force against the protests (2011 Progress Report, p.27). The EU underlines that some of the representatives of Confederation of Public Workers' Unions (Kamu Emekçileri Sendikaları Konfederasyonu) and Education and Science Workers' Union (Eğitim ve Bilim Emekçileri Sendikası) are judged with the claims of being PKK members. It is expressed that those developments are the results of broad definition of terrorism in Turkey, which cause restrictions on freedom of association and freedom of expression. According to the decision of ECHR, Turkey violated Article 10 (freedom of expression) and Article 11 (freedom of assembly and association) of the ECHR on the closure case of Eğitim-Sen because of its support for the right to mother tongue education in its constitution (2013 Progress Report, p.54). In 2011, firstly in the history of Turkey, public servants in Ministry of Defense and Turkish Armed Forces established Civilian Public Servants Union (Sivil Memurlar Sendikas1-Sime-Sen). However, a closure case was presented by Ankara governorate to 8th Labour Court with the reason that the union violated Law No. 4688 on Public Servants' Trade Unions in the constitution. The Court sent the case to the Constitutional Court since it contradicted with the ILO Agreements and the constitution. The Constitutional Court decided that Article 51 and Article 90 of the constitution let public servants to establish trade union organizations. On September 27, 2013, Ankara 8th Labour Court decided that the Law No. 4688 Article 15/G must have been repealed since it constrained union rights of the public servants which were under the protection of international agreements Turkey signed (http://www.simesen.org.tr). Another initiative of police officers to establish a trade union with the name of Emniyet-Sen was rejected by Ankara governorate based on the same law in the constitution. However 9th Labour Court moved the case directly to the Constitutional Court. On the other hand, despite of the bureaucratic obstacles, Union of Judges was established in 2012 (2013 Progress Report, p.54).

After Croatia became an EU candidate country in 2004, amendments in Labour Law became an obligation in order to harmonize with the EU acquis on social policy. Significant steps have been taken since 2005. For instance, property-related problems of trade unions were solved. There were restrictions on the workers' rights, especially on the right to strike (2006 Progress Report, p.10). Those problems were refrained from the weak public administration, economic problems in the country and the poorly functioning judiciary (2007 and 2008 Progress Reports, p.12). The government accelerated the reform process, and after 18 months of consultations and negotiations 
Ünalp Çepel, Z. (2015). Europeanization of Union Rights: A comparative analysis between Turkey and Croatia. International Journal of Social Sciences and Education Research, 1 (2), 355-366.

between the social partners, the new Labour Law came into force in 2009. Therefore trade unions started to have a voice in collective bargaining processes and influence political decisions (2009 Progress Report, p.13). In Croatia, the negative result of the harmonization process on labour legislation has been labour market flexibility and liberalization. As a reaction to this result, trade unions in the country have struggled to limit fixed short-term contracts in the labour market (ITUC, 2010, p.1). In 1997, the State Inspectorate was established in Croatia under the state administration in order to inspect the application of regulations in the fields of labour relations, health and safety in the workplace. However, weak administrative capacity of the institution had been criticized by the EU in 2006 (European Commission, 2006, p.9). In this regard, Croatian government increased the number of labour inspectors, encouraged them to develop their skills, and provided better technical equipment (Eurofound, 2012, p.7). Despite of the efforts, labour disputes were not solved effectively. Then, a specialised court with the name of Municipal Labour Court was established in Zagreb in 2011 (2011 Progress Report, p.11).

In 2012, Law No. 6356 on Trade Unions and Collective Bargaining Agreements came into force in Turkey. Significant reforms were held on union rights especially in 'facilitating the internal functioning of trade unions, easing membership procedures and requirements, limiting the prohibition of strikes, and reducing penal provisions' (2013 Progress Report, p.39). The conditions of 'being Turkish citizen, being literate in Turkish and working actively in the branch of activity that the trade union is established' were repealed. And membership age was decreased from sixteen to fifteen (Dereli, 2013, pp.44,45). With the new law, the number of branches of activity was decreased from 28 to 20; Ministry of Labour and Social Security had the authority to determine the branch of activity in which a workplace was included; and membership to a trade union organization was based on an electronic application system operated by the Ministry (ILO, 2012). Representation rate of branches was reduced to three per cent. Before the law came into force, some aspects of the law were criticized by different national and international institutions. National trade unions draw the attention to the three per cent of branches and declared that it would have caused the workers not to find a collective bargaining agency in some branches of activity; and 29 of 50 collective bargaining agencies would have lost their rights. They resisted, and demanded the law to be vetoed (Dereli, 2013, p.57). On the other hand, International Trade Union Confederation and European Trade Union Confederation sent a letter to President of that term, Abdullah Gül, telling that the legislation passed in the parliament should have been vetoed. Legislative and bureaucratic obstacles for trade union organizations were emphasized also by the EU in the 2013 and 2014 Progress Reports for Turkey. Especially limitations on right to organize and right to strike for public servants, weak functioning of tripartite and bipartite social dialogue mechanisms were criticized (Turkey 2013 Progress Report, pp.39,54; 2014 Progress Report, p.40). Even though a new labour law was enacted as a reform initiative by the government, interpretations and evaluations on the law have been mostly critical.

\subsection{Social dialogue in Turkey and Croatia}

Trade unions are one of the important components of social dialogue mechanisms. In Turkey, Confederation of Turkish Trade Unions (Türkiye İşşi Sendikaları Konfederasyonu), Hak-İş Confederation (Hak İşçi Sendikaları Konfederasyonu), and Confederation of Progressive Trade Unions of Turkey (Devrimci İşçi Sendikaları Konfederasyonu) participate in the dialogue mechanisms as social partners. There are five types of social dialogue mechanisms in Turkey: Labour Assembly, Economic and Social Council, Minimum Wage Board, Supreme Arbitration Board, 
Ünalp Çepel, Z. (2015). Europeanization of Union Rights: A comparative analysis between Turkey and Croatia. International Journal of Social Sciences and Education Research, 1 (2), 355-366.

and Tripartite Consultation Board. Labour Assembly was established as the first tripartite institution in 1945. This consultative body cannot meet since 2004. Economic and Social Council was established in 1995 after Customs Union Agreement had been signed between Turkey and the EU. However the Council started to function effectively in 2001 after Law No. 4641 on Economic and Social Council had come into force (http://esk.dpt.gov.tr). In the Council, the government have had a predominant role in determining the agenda and putting the results. This consultative body cannot meet since 2009 , and that is criticized by the EU in the progress reports. That poses a significant threat to the Europeanization process. Because one of the political conditions has not been met by the Turkish authorities without any reason or declaration. Another mechanism, Minimum Wage Board designates minimum wages for workers under employment contracts. Supreme Arbitration Board deals with the conflicts on collective agreements and strikes. With the establishment of Tripartite Consultation Board, Ministry of Labour and Social Security started to consult employees' and employers' representatives about issues on working life (Dinler, 2012, p.12). However the common problem in social dialogue mechanisms is the predominance of the government. Turkey needs to strengthen the role of trade unions by increasing the numbers of their representatives and guarantee to maintain meetings of the dialogue institutions within regular periods.

Social dialogue mechanisms have developed in Croatia since 1994. With the establishment of Economic and Social Committee, trade unions started to participate in this highest tripartite social dialogue mechanism. Union of Autonomous Trade Unions of Croatia (SSSH), Association of Croatian Public Sector Trade Unions, Independent Trade Unions of Croatia, Croatian Association of Trade Unions, and Workers' Trade Union Association of Croatia are represented in the Committee (Office for Social Partnership in Croatia, 2010, p. 2). It is argued that Croatian trade unions are strong because they have societal power but are weak because they cannot influence political decisions (Grdesic, 2008, p.145). There are six representatives of each group; the government, the employers' organizations and the trade unions (Pavić-Rogošić, 2008, p.5). In order to support the Committee, Office for Social Partnership was established under the state administration. Economic and social committees are established also at the local level in order to expand consultation and discussion culture to the whole country (Eurofound, 2012, p.6).

The largest trade union federation in Croatia, the SSSH signed the 'Agreement for a Legal Croatia' with opposition parties in 1999. The agreement was about 25 requests in order to promote social partnership (Cvijetic, 1999). Those parties gained the majority of the votes in the elections in 2000. In 2002, another agreement 'Partnership for Development' on wages, benefits and privatization preferences was signed by the government, the employers federation and four trade unions (Stubbs and Zrinšèak, 2005, p.174). This has also contributed to the development of social dialogue in Croatia. However social dialogue mechanisms in the country started to function more systematically during the EU candidacy process. A 'National Committee for the Supervision of Croatia's Membership Talks with the European Union' was established under the parliament in 2005. This committee constructed a dialogue atmosphere of parliamentarians, business organizations and trade unions and has contributed to the harmonization process (2005 Progress Report p.8). Despite of the legal and institutional reforms, problems have arised in practice. In response, trade unions' representatives declared that they abandoned 'Agreement for a Legal Croatia' which was signed with the government. Although social dialogue mechanisms were strengthened during the accession process, trade unions remained as the weakest side of the consultations and discussions (Stubbs and Zrinšèak, 2005, p.175). In 2010, the government brought amendments to the 
Ünalp Çepel, Z. (2015). Europeanization of Union Rights: A comparative analysis between Turkey and Croatia. International Journal of Social Sciences and Education Research, 1 (2), 355-366.

Labour Law on collective agreements only by parliamentary procedure, but without consulting to social partners (Pezelj, 2011, p.7). In this regard, trade union representatives abandoned to participate in the meetings of Economic and Social Committee in 2011 in order to show their opposition to the government policies. As a result, the Committee meetings have suspended for ten months (2010 Progress Report, p.12; 2011 Progress Report, p.11). Both trade unions and employer organizations are dissatisfied with social dialogue processes in the country. In December 2013, trade unions left the Economic and Social Council because of the newly proposed law on occasional work and rising the retirement age to 67 (Seperic, 2014, p.2). According to Poloski Vokic and Obadic, trade unions in Croatia should reach consensus firstly among themselves, recruit new members, mobilize members for industrial action, encourage leaders to develop more democratic leadership style promote union democracy and use information technology in union activities (Poloski Vokic and Obadic, 2014, p.532). Even if the problems between the sides, trade unions in Croatia have shown great effort to be strong in the dialogue mechanisms. That has been dealt with the commitment of state elites and civil society elements to the Europeanization process and the final objective - EU membership.

\section{Conclusion}

Both in Turkey and Croatia, freedom of association is under the guarantee of the laws. However in contrast with Croatia, Turkey does not meet ILO standards on the Conventions No. 87 (the freedom of association and protection of the right to organize) and 98 (the right to organize and collective bargaining). Although there are no problems for public servants in Croatia to establish trade union organizations, Turkey is in a transition period.

Government is predominant in the social dialogue mechanisms of Turkey. The meetings of social dialogue mechanisms are irregular. Even the decision to meet is taken by the government. However the meetings are held regularly in Croatia. Trade unions are strong enough to cut down the meetings if they oppose decisions of the government. In contrast with Croatia, there are more representatives of government than the trade union organizations in social dialogue mechanisms of Turkey.

The comparative analysis on Turkey and Croatia indicates that freedom of association and social dialogue mechanisms in Croatia have not been priority areas for the EU. Because the country has been successful in the steps of Europeanization. The government and social partners aimed to overcome the rest of the problems in the labor market, and work for the ratification of Revised European Social Charter. The EU political conditionality and harmonization with the EU acquis on union rights have been met and sustained successfully. However the same issues have not been in the agenda of Turkey. Inadequate reforms and bureaucratic obstacles on union rights have caused violation of fundamental rights which were recognized in the constitution, and suspension of the Europeanization process.

\section{References}

Balkır, C. \& Aknur, M. (2015). Different Trajectories yet the Same Substance: Croatia and Turkey. Anne Wetzel and Jan Orbie (Ed.s) in The Substance of EU Democracy Promotion (85-103). London: Palgrave Macmillan. 
Ünalp Çepel, Z. (2015). Europeanization of Union Rights: A comparative analysis between Turkey and Croatia. International Journal of Social Sciences and Education Research, 1 (2), 355-366.

Börzel, T. A. (2011). When Europeanization Hits Limited Statehood. KFG Working Paper Series. 30, 117, Advance online publication. http://userpage.fu-berlin.de/kfgeu/kfgwp/wpseries/WorkingPaperKFG_30.pdf

Börzel, T. A. \& Risse, T. (2000). When Europe Hits Home: Europeanization and Domestic Change. European Integration online Papers. 4 (15), 1-20.

Cerami, A. (2008). Europeanization and Social Policy in Central and Eastern Europe. François Bafoil and Timm Beichelt (Eds.). in Européanisation D’Ouest en Est. Coll. Logiques Politiques (137-168). Paris: L'Harmattan.

Čehulić-Vukadinović, L. (2013) Croatia's Entry into the European Union and Perspectives of Further EU Enlargement to the Western Balkans. Megatrend Review. 10 (3), 49-64.

Cierco, T. (2009). Europeanization Impact on Croatia's Course to Democracy. Primavera. 4 (122), 173 201.

Council of Europe. (2013). Croatia and the European Social Charter. http://www.coe.int/t/dghl/monitoring/socialcharter/countryfactsheets/Croatia_en.pdf

Council of Europe. (1997). The Right to Organize and to Bargain Collectively Protection Within the European Social Charter. Human Rights Social Charter Monographs (Report No: 5). Brussels: Council of Europe Publishing.

Cvijetic, S. (1999) News Review for Croatia. Central Europe Review, 1 (19). Advance online publication. http://www.ce-review.org/99/19/croatianews19.html

Dağı, İ. (1997). İnsan Hakları ve Demokratikleşme: Türkiye-Avrupa Birliği İlişsilerinde Siyasal Boyut. Atilla Eralp (Ed.) in Türkiye ve Avrupa (Batılılaşma Kalkınma Demokrasi, (121-176). Ankara: İmge Kitabevi.

Dereli, T. (2013). 6356 Sayılı Yeni Sendikalar ve Toplu İş Sözleşmesi Kanunu: Genel Bir Değerlendirme. Çalışma ve Toplum. 1, 41-64.

Dinler, D. Ş. (2012). Trade Unions in Turkey. Friedrich Ebert Stiftung, Advance online publication. http://library.fes.de/pdf-files/id-moe/09536-20121221.pdf

European Commission. (2012). Communication from the Commission to the European Parliament and the Council on the Main Findings of the Comprehensive Monitoring Report on Croatia's state of preparedness for EU Membership. COM(2012) 601. Brussels.

European Commission. (2011). Consulting European Social Partners: Understanding How it Works. Brussels. http://ec.europa.eu/social/BlobServlet?docId =7208\&langId=en

European Commission. Croatia 2005- 2011 Progress Reports. Brussels.

European Commission. Screening Report Croatia. Brussels. http://ec.europa.eu/enlargement/pdf/croatia/screening_reports/screening_report_19_hr_internet_en.pdf

European Commission. Social Dialogue. Advance online publication. http://ec.europa.eu/social/main.jsp?catId=329\&langId=en

European Commission. (2004) Strategy Paper of the European Commission on Progress in the Enlargement Process. COM(2004) 657 final. Brussels.

European Commission. Turkey 1998-2014 Progress Reports, Brussels.

Eurofound. (2012) Croatia: Industrial Relations Profile. Advance online publication. http://www.eurofound.europa.eu/eiro/country/croatia.pdf 
Ünalp Çepel, Z. (2015). Europeanization of Union Rights: A comparative analysis between Turkey and Croatia. International Journal of Social Sciences and Education Research, 1 (2), 355-366.

EU Charter of Fundamental Rights. http://www.eucharter.org/home.php? page_id=1

Featherstone, K. \& Radaelli C. (Ed.s). (2003). The Politics of Europeanization. Oxford University Press.

Grdesic, M. (2008). Mapping the Paths of the Yugoslav Model: Labour Strength and Weakness in Slovenia, Croatia and Serbia. European Journal of Industrial Relations. 14 (2), pp. 133-151.

Gülmez, M. (2007). Gözden Geçirilmiş Avrupa Sosyal Şartına Uyum Sağlayabilecek miyiz? Çalışma ve Toplum. 1, 27-52.

Güray, M. (2013) Avrupa Birliği'nde Sosyal Diyalog. Çalışma Dünyası Dergisi. 1 (1), 144-158.

Huntington, S. P. (1996). The Clash of Civilizations and the Remaking of World Order. New York: Simon and Schuster.

ILO Official Journal. (2012) Turkey-Law on Trade Unions and Collective Labour Agreements. Law No. 6356, 28460. Advance online publication. http://www.ilo.org/dyn/natlex/docs/MONOGRAPH/91814/106961/F2018685492/TUR91814\%20Eng.pdf

ILO, Social Dialogue. Advance online publication. http://www.ilo.org/ipec/Action/social-dialogue/lang-en/index.htm

International Trade Union Confederation (ITUC). (2010). Internationally Recognised Core Labour Standards in Croatia. Report for the WTO General Council Review of the Trade Policies of Croatia. Geneva. http://www.ituc-csi.org/IMG/pdf/CLC_Croatia.pdf

Kaczorowska, A. (2011). European Union Law. London, New York: Routledge.

Kaliber, A. (2013). Contextual and Contested: Reassessing Europeanization in the Case of Turkey. International Relations. 27(52), 52-73.

Office for Social Partnership in Croatia. (2010). Social Dialogue in the Republic of Croatia. http://www.aicesis.org/IMG/doc_101122_Social_Dialogue_in_Croatia.doc

Official Journal of the European Union. (2010). Consolidated Version of the Treaty on the Functioning of the European Union. Advance online publication. http://eur-lex.europa.eu/LexUriServ/LexUriServ.do?uri=OJ:C:2010:083: 0047:0200:en:PDF

Pavić-Rogošić, L. (2008). Civil and Social Dialogue in Croatia. Advance online publication. http://www.odraz.hr/media/69001/civil\%20and\%20social\% 20dialogue\%20in\%20croatia.pdf

Pezelj, A. M. (2011). Annual Review 2010 on Labour Relations and Social Dialogue in South East Europe: Croatia, Friedrich Ebert Stiftung. Advance online publication. www.fessoe.de

Poloski Vokic, N. and Obadic, A. (2014). The Future of Trade Unions in Croatia - Various Stakeholders' Perspectives. Transfer. 20 (4), 521-536.

Public Services International. (2012) Global Unions Urge Turkish President to Veto New Trade Law. Advance online publication. http://www.world-psi.org/en/global-unions-urge-turkish-president-veto-newtrade-union-law

Sime-Sen. (2013). Sendikal Yasă̆ın Kalkma Süreci ve Sime-Sen. Advance online publication. http://www.simesen.org.tr/tarihce.html

Sime-Sen Yarg1 Süreci. http://simesen.org.tr/kapatma-davasi-dosyalari.html

Schimmelfennig, F. \& Sedelmeier U. (2005). Europeanization of Central and Eastern Europe. USA: Cornell University Press.

Sedelmeier, U. (2011). Europeanization in New Member and Candidate States. Living Reviews in European Governance. 6 (1), 5-32. 
Ünalp Çepel, Z. (2015). Europeanization of Union Rights: A comparative analysis between Turkey and Croatia. International Journal of Social Sciences and Education Research, 1 (2), 355-366.

Seperic, D. (2014). 2013 Annual Review of Labour Relations and Social Dialogue in South East Europe: Croatia. Friedrich-Ebert-Stiftung. Advance online publication. www.fessoe.de

Stubbs, P., Zrinšèak, S. (2005). Extended Social Europe? Social Policy, Social Inclusion and Social Dialogue in Croaita and the European Union. Katarina Ott (Ed.) in Croatian Accession to the European Union: Facing the Challenges of Negotiations. (161-184). Zagreb.

T.C. Kalkınma Bakanlığı. Ekonomik ve Sosyal Konsey. Advance online publication. http://esk.dpt.gov.tr/ESK.portal

The Minimum Wage Board. Advance online publication. http://industrialrelationsinturkey.com/social-dialogue-institutions/the-minimum-wage-board/

Tocci, N. (2009). Europeanization in Turkey: Trigger or Anchor for Reform?. South European Society and Politics. 10 (1), 73-83.

Usul, A. R. (2011). Democracy in Turkey. The Impact of EU Political Conditionality. London, New York: Routledge.

Vaughan, B. \& Kilcommins, S. (2007). The Europeanization of Human Rights: An Obstacle to Authoritarian Policing in Ireland. European Journal of Criminology. 4 (4), 437-460. 